ORIGINAL ARTICLE

\title{
Progesterone supplementation for prevention of preterm birth.
}

\author{
Saadia Bano', Nadia Sharif ${ }^{2}$, Uzma Shehzad ${ }^{3}$, Uzma Manzoor $^{4}$, Iram Aslam5, Khalid Mustafa ${ }^{6}$
}

Article Citation: Bano S, Sharif N, Shehzad U, Manzoor U, Aslam I, Mustafa K. Progesterone supplementation for prevention of preterm birth. Professional Med J 2022; 29(1):41-45. https://doi.org/10.29309/TPMJ/2022.29.01.6571

ABSTRACT... Objective: To study the efficacy of Progesterone supplementation for prevention of preterm birth. Study Design: Descriptive Interventional Study. Setting: Department of Obstetrics and Gynecology at Independent University Hospital, Faisalabad. Period: January 2018 to December 2020. Material \& Methods: Data collected by using Non probability consecutive sampling techniques. Total 156 patients were included in study. Data was collected after informed consent, on pre designed proforma. Patient presented in $1^{\text {st }}$ trimester and having previous history spontaneous preterm labour and recurrent miscarriages. We included patient presenting after 24 weeks of pregnancy and patient having threatened or actual preterm labour. Results: Among 156 patients, more than $82 \%$ of patient were delivered after 34 weeks of gestation and $18 \%$ were delivered before 34 weeks of gestation. Fetal outcome was very good in those patients who were delivered after 34 weeks of gestation with the use of Prophylactic progesterone therapy. Conclusion: Prophylactic use of progesterone helps in prolongation of pregnancy beyond 36 weeks and also help in decreasing the morbidity associated with premature delivery.

Key words: $\quad$ Preterm Labour, Prophylactic Progesterone Therapy, 17 Alpha Hydroxyprogesterone Caproate 250mg.

\section{INTRODUCTION}

Preterm birth is defined as delivery of a baby before 37 completed weeks of pregnancy. Preterm Birth is unpredictable, in $80 \%$ of all preterm deliveries usually the baby is single. Most of these deliveries are due to spontaneous onset of contraction or due to Spontaneous premature rupture of membranes. The rate of iatrogenic premature deliveries based on obstetrician decision has also increased for indication like induction of labour for obstetric or medical problems, like Severe Fetal growth restriction, severe Preeclampsia and previous history of surgery. The major risk factor for preterm labour are history of previous preterm delivery and recurrent second trimester miscarriages. Many maternal risk factors increase the risk of preterm delivery like addiction malnutrition, anemia, high glucose intake. ${ }^{1}$

It has been proven in many studies that intervention like hydration, antibiotics, steroid cover and tocolytics can only delay delivery for a period of 24 to 48 hours in patients presenting with preterm labour. This has shifted the focus towards the prevention of preterm labour. ${ }^{2}$

The prevention of Preterm Birth by different medication has remained unsuccessful. But the recent approval of progesterone supplementation for the long term use in second half of pregnancy has created a hope for prevention of preterm birth. The effect of progesterone is to maintain uterine quiescence in $1^{\text {st }}$ and $2^{\text {nd }}$ half of pregnancy by suppressing the production of stimulatory prostaglandins and inhibition of the expression of contraction associated protein genes within myometrium, so further preventing uterine contraction The onset of labour both preterm and at term is associated with a functional withdrawal of progesterone activity at the level of uterus. ${ }^{3}$

Progesterone has been administered to pregnant women for several reasons, including threatened miscarriage, recurrent miscarriage, prevention
1. FCPS, Associate Professor Gynae \& Obs, Independent Medical College Faisalabad.

2. FCPS, Associate Professor Gynae \& Obs, Independent Medical College Faisalabad.

3. FCPS, Associate Professor Gynae \& Obs, Independent Medical College Faisalabad.

4. FCPS, Associate Professor Gynae \& Obs, Independent Medical College Faisalabad.

5. FCPS, Associate Professor Gynae \& Obs, Independent Medical College Faisalabad.

6. FCPS, Assistant Professor Physiology, Independent Medical College Faisalabad.

\author{
Correspondence Address: \\ Dr. Saadia Bano \\ Department of Gynae \& Obs \\ Independent Medical College Faisalabad. \\ saadia15477@yahoo.com
}

Article received on:

$06 / 05 / 2021$

Accepted for publication:

$04 / 11 / 202$ 
of preterm labour and luteal support during in vitro fertilization treatment. ${ }^{4}$ There was a fear for masculinisation of the female fetus by prolong iatrogenic use of progesterone whoever research among exposed women showed that there is no difference in the development of all systems including the central nerve system, limbs and joints, urogenital tract and circulatory tract between treated and untreated pregnancies, even when 170HPC was administered in early pregnancy. ${ }^{5}$ The effectiveness of 17P in reducing preterm delivery (PTD) in at-risk pregnancies was first proven in the 1970s. ${ }^{6}$

This explains the use of progesterone supplementation for prevention of preterm labour and birth. Progesterone is given in the form of injection and Vaginal suppository, that are easily available to patient and depending upon patient choice and sometime combined approach is also used in some patient.

\section{MATERIAL \& METHODS}

This study was a single centre descriptive interventional study that was conducted in Obstetrics and Gynaecology Department of Independent medical college Faisalabad from Jan 2019 to Dec 2020. The study was approved by institutional review board (IUH/IRB/000034). Patients were informed and detailed history of patient were taken at booking were followed according to requirement and time and mode of delivery was recorded. Fetal outcome was also observed. Patient were interviewed later on regarding satisfaction as well. Total 156 patients were included in study according to inclusion and exclusion criteria.

\section{Inclusion Criteria}

- History of recurrent $1^{\text {st }}$ Trimester Miscarriage.

- History of recurrent $2^{\text {nd }}$ Trimester Miscarriage.

- History of spontaneous preterm Delivery.

- History of latrogenic premature delivery due to Obstetric and medical problems like IUGR, Oligohydroamnios, Pre eclampsia, placental abruption, impending scar dehiscence, polyhydramnios etc.

- Patient with Cervical cerclage were also included in study.

\section{Exclusion Criteria}

- Patient having booking after 24 weeks of pregnancy.

- Patient presented with threatened preterm or actual preterm labour.

- Patient having congenitally abnormal baby.

The integrated safety data demonstrate a favorable safety profile of 17 Alpha Hydroxyprogesterone Caproate during pregnancy. So all selected patient underwent a weekly administration of 17 Alpha Hydroxyprogesterone Caproate 250mg intramuscularly from booking till 36 weeks of pregnancy. However in few patients there was need for additional progesterone therapy in the form of vaginal suppository who presented with lower abdominal pain and backache.

\section{RESULTS}

A total of 156 patient who presented in Gynae OPD and emergency were included in study after informed consent. Their history was recorded on pre designed proforma and patient counseling was done for follow up visit. Later on their time and mode of delivery was also recorded and fetal outcome observed. Distribution of patients according to the age, parity and previous obstetrics history are given in Table-I, Table-II \& Table-III respectively.

\begin{tabular}{|l|c|}
\hline \multicolumn{1}{|c|}{ Age } & No. of Patients (\%) \\
\hline $20-25$ years & $24(15.3 \%)$ \\
\hline $26-30$ years & $68(43.5 \%)$ \\
\hline 31-35 years & $64(41.2 \%)$ \\
\hline Total & $156(100 \%)$ \\
\hline \multicolumn{1}{|c|}{ Table-I. Distribution of patient according to age. } \\
\hline \multicolumn{1}{|c|}{ Parity } & No. of Patients (\%) \\
\hline P0 & $89(57.0 \%)$ \\
\hline P1 & $42(26.9 \%)$ \\
\hline P2 & $15(9.6 \%)$ \\
\hline P3 & $10(6.4 \%)$ \\
\hline Total & $156(100 \%)$ \\
\hline
\end{tabular}

Table-II. Distribution of patient according to parity. 


\begin{tabular}{|l|c|}
\hline \multicolumn{1}{|c|}{ History } & $\begin{array}{c}\text { No. of } \\
\text { Patients }\end{array}$ \\
\hline $\begin{array}{l}\text { History of recurrent } 1^{\text {st }} \text { Trimester } \\
\text { Miscarriage. }\end{array}$ & 20 \\
\hline History of one $2^{\text {nd }}$ Trimester Miscarriage. & 35 \\
\hline History of two $2^{\text {nd }}$ Trimester Miscarriage & 34 \\
\hline History of one preterm delivery. & 42 \\
\hline History of 2 or more preterm delivery & 15 \\
\hline $\begin{array}{l}\text { History of latrogenic preterm delivery } \\
\text { History of Cervical cerclage in current } \\
\text { pregnancy. } \\
\text { Table-III. Distribution of patient according to obstetric } \\
\text { history. }\end{array}$ & 10 \\
\hline
\end{tabular}

In all selected patients prophylactic progesterone therapy started in the form of injectible progesterone 17 Alpha Hydroxyprogesterone Caproate $250 \mathrm{mg}$ intramuscularly on weekly interval for prevention of miscarriage and preterm labour. In $30-40 \%$ of patients in which there were symptoms of heaviness, lower abdominal pain and backache, combined approach used in the form of oral or vaginal progesterone on intermittent basis given with continuous weekly injectible progesterone. By this approach 61.5\% of patients delivered after 36 weeks with good pregnancy outcome. The results are shown in Table-IV.

\begin{tabular}{|l|c|}
\hline \multicolumn{1}{|c|}{$\begin{array}{c}\text { Gestational age at the } \\
\text { time of delivery }\end{array}$} & No. of Patients \\
\hline$>36$ weeks & $96(61.5 \%)$ \\
\hline $34-36$ weeks & $34(21.7 \%)$ \\
\hline $32-34$ weeks & $21(12.1 \%)$ \\
\hline $30-32$ weeks & $7(4.5 \%)$ \\
\hline$<30$ weeks & $0(0)$ \\
\hline Total & $156(100 \%)$ \\
\hline \multicolumn{2}{|c|}{ Table-IV. Distribution of patient according to } \\
gestational age. (at the time of delivery)
\end{tabular}

So this study showed that prophylactic progesterone therapy resulted in good outcome, more than $82 \%$ were delivered after 34 weeks of gestation and only $18 \%$ of the patients delivered less than 34 weeks of gestation and only 5\% of patients have very premature delivery with adverse fetal outcome while in others there were improvement in Perinatal outcome. Patient satisfaction was observed in more than $80 \%$ of patients. So it was observed that prophylactic progesterone therapy is beneficial for patients with bad obstetric history. It will increase their chances of delivery with good fetal outcome. No adverse side effect was observed with its use. Patient's satisfaction was also very high.

\section{DISCUSSION}

There is increasing evidence that progesterone supplementation can reduce the rate of spontaneous preterm birth in women in which there is strong evidence of prior spontaneous preterm birth and recurrent Miscarriage. On this basis, All patients of Reproductive age group ranging from 20-35 included in group study. Maximum patients were of 26-35 age group with previous bad pregnancy outcomes in form of Recurrent Miscarriage and having no alive issues due to previous premature deliveries. In all these patients, injection 17 Alpha Hydroxyprogesterone Caproate 250mg given intramuscularly weekly from booking till 34-36 of gestation. By this in selected group $61.5 \%$ of patients delivered after 36 weeks of gestation with good fetal outcome, $21.7 \%$ after 34 weeks and $12 \%$ after 32 weeks. Babies who delivered before 34 weeks, there was requirement for the neonatal admission and only $4.5 \%$ of patients delivered at less than 32 weeks with adverse fetal outcome. However it improved the hope of patients with prolongation of pregnancy close to term.

The result of study are comparable to study conducted by eis and investigators who selected total 459 patients in their study in which there was a well-defined history of spontaneous preterm labour. In these patients weekly Intramuscular injection of 17 hydroxy progesterone (250mg) started at 16-20 weeks of pregnancy and continued until 36 weeks. In these woman's the outcome was very good. The percentage of delivery at $<37$ weeks was $36 \%<35$ weeks $21 \%$ and $<32$ weeks $11 \% .{ }^{7}$ The da Foncseca and coinvestigators conducted a trial in Brazil in which women randomized to progesterone prophylaxis had a significantly reduced risk of recurrent preterm birth at all gestational ages $<37$ weeks (14\% vs $29 \%$ in placebo groups and $<34$ weeks (3\% vs $19 \%){ }^{8}$ 
While in contrast to this study, the results of PROLONG study were published in October 2019. There was no significant difference in either Preterm birth before 35 weeks (11.0\% vs $11.5 \%)$ or neonatal morbidity index (5.6 vs $5.0 \%$ ) between the two groups. ${ }^{9}$

A review study that was conducted by Tita and Rouse showed that the 17 Alpha Hydroxyprogesterone use in patient with a history of spontaneous preterm labour effectively reduces the incidence of recurrent preterm Labour. ${ }^{10}$ American College of Gynaecologist also support the use of hydroxyprogesterone acetate for the prevention of preterm birth and SMFM also support the use of Hydroxyprogesterone acetate but only in high risk cases that is similar to the trial of Meis et al. ${ }^{7}$ Multiple studies done in patient having incompetent or short cervix in which cervical cerclage and prolong use of injection hydroxyprogesterone caproate was found to be very effective., ${ }^{11}$

So this study provide evidence in support of the use of progesterone especially 17 alpha Hydroxyprogesterone caproate $250 \mathrm{mg}$ weekly from booking to 36 weeks to prevent adverse pregnancy outcome. 17 alpha hydroxyprogesterone caproate is natural progesterone without any significant adverse maternal and fetal side effect so it can be used safely. It is also cost effective.

\section{CONCLUSION}

Now a days, prophylactic use of injectible progesterone, pessary and cervical cerclage in women with high risk of preterm birth has been reported to reduce the incidence of preterm birth and improve neonatal outcome. So identification of risk factors early in pregnancy is an essential component of good obstetrics case. Since early intervention may be effective in reducing the risk factors of preterm birth.

Copyright@ 04 Nov, 2021.

\section{REFERENCES}

1. Parkinson JR, Hyde MJ, Gale C, Santhakumaran S, MODI N. Preterm birth and the metabolic Syndrome in adult life: A systematic review and meta-analysis. Pediatrics 2013; 131:e 1240-63.

2. Bukowski R, Malone FD, porterFT, et al. Preconceptional folate supplementation and the risk of spontaneous preterm birth: a cohort study. Plos Med. 2009; e10000061.[PMC free article] [pubMed] [Google scholar].

3. Challis JRG, Mattews SG, Gibb w, Lye SJ. Endocrine and paracrine regulation of birth at term and preterm. Endocr Rev.2000; 21(5): 514-550. [Abstract] [Google scholar].

4. Daya S, Gunby J. Luteal phase support in assisted reproduction cycles. Cochrane database Syst rev 2004; (1): CD004830.

5. Dudas I, Gidai J, Czeizel AE. Population-based casecontrol teratogenic study of hydroxyprogesterone. 2006; 46:194-198.

6. Dodd JM, Flenady V, cincotta R, Crowther CA. Prenatal administration of progesterone for preventing preterm birth. Cochrane database Syst Rev 2006; (1) CD004947.

7. Meis PJ, Klebanoff M, Thom E, et al. National institute of child health and Human Development Maternal -Fetal Medicine Units Network. Prevention of recurrent preterm delivery by 17 alpha hydroxyprogesteronr caproate. N Engl J Med. 2003; 348:2379-2385. [Pub Med] [Google scholar].

8. Da Fonseca EB, Bittar RE, Carvalho MH, Zugaib M. Prophylatic administration of progesterone by vaginal suppository to reduce the incidence of spontaneous preterm bieth in a women at increased risk; A randomized placebo-controlled double-blind study. Am J Obstet Gynaecol. 2003; 188: 419-424. [Pub Med] [Google scholar].

9. Blackwell SC, Gyamfi-Bannerman C, Biggio JR Jr, et al. 17=OHPC to prevent recurrent preterm Birth in Singleton Gestations (PROLONG Study): A multicenter, international, randomized double-blind trial. Am J perinatal. 2019; 37: 127-136.

10. Tita AT, rouse DJ. Progesterone for preterm birth prevention: An evolving intervention. Am J obstet Gynaecol. 2009; 200(3): 219-224. [Abstract] [Google scholar]. 
11. Romero $\mathrm{R}$, Nicolaides $\mathrm{KH}$, Conde-Augudelo $\mathrm{A}$, et al. Vaginal progesterone decreases preterm birth $</=34$ weeks of gestation in women with a singleton pregnancy and a short cervix: An updated metaanalyses including data from the OPPTIMUM study. Ultrasound Ovstet Gynaecol. 2016; 48: 308-317.

\begin{tabular}{|c|c|c|c|}
\hline \multicolumn{4}{|c|}{ AUTHORSHIP AND CONTRIBUTION DECLARATION } \\
\hline No. & Author(s) Full Name & Contribution to the paper & Author(s) Signature \\
\hline 1 & Saadia Bano & $\begin{array}{l}\text { Study design, Data collection and } \\
\text { interpretation of manuscript writing, } \\
\text { Literature review. }\end{array}$ & didicishung \\
\hline 3 & Uzma Shehzad & Data collection. & $U_{3 m a}$ Snathins \\
\hline 4 & Uzma Manzoor & References writing. & $+33^{m o} \operatorname{mos} 3 c^{2} \cdot$ \\
\hline 5 & Iram Aslam & Review article. & iram arlam \\
\hline 6 & Khalid Mustafa & Review article. & Hincin An $=8$ \\
\hline
\end{tabular}

